\title{
Larval trematode infections in Lymnaea glabra populations living in the Brenne Regional Natural Park, central France
}

\author{
Daniel Rondelaud, Philippe Vignoles, and Gilles Dreyfuss* \\ INSERM 1094, Faculties of Medicine and Pharmacy, 87025 Limoges, France
}

Received 2 September 2015, Accepted 28 November 2015, Published online 21 December 2015

\begin{abstract}
Lymnaea glabra is known to be a natural intermediate host of two flukes, Calicophoron daubneyi and Fasciola hepatica, in central France. But it can also sustain larval development of other digeneans. Adult snails were thus collected from 206 habitats in 2014 and 2015 to identify parasite species and determine the prevalence of each digenean infection in relation to the five types of snail habitats. Seven digenean species were noted in 321 infected snails (out of 17,647 L. glabra). Snails with F. hepatica or C. daubneyi were found in $14.5 \%$ and $12.6 \%$ of habitats, respectively. Percentages were lower for snails with Opisthoglyphe ranae (5.8\%), Haplometra cylindracea (5.3\%) and were less than 5\% for those infected with Echinostoma revolutum, Notocotylus sp. or Plagiorchis sp. Prevalence noted for each parasite species varied with the type of habitat. The number of species in L. glabra was lower than that found in $G$. truncatula from the same region (7 instead of 10). The distribution and prevalence of each digenean species were thus dependent on the type and location of each snail habitat.
\end{abstract}

Key words: Brenne Regional Natural Park, Cercaria, Digenean, Lymnaea glabra, Lymnaeidae, Snail.

Résumé - Infections par des larves de Trématodes chez des populations de Lymnaea glabra vivant dans le Parc Naturel Régional de la Brenne, centre de la France. Lymnaea glabra est connu comme un hôte intermédiaire naturel de deux douves, Calicophoron daubneyi et Fasciola hepatica, dans le centre de la France. Mais cette limnée peut aussi soutenir le développement larvaire d'autres Digènes. Des L. glabra adultes ont été récoltés pour cela dans 206 habitats en 2014 et 2015 pour identifier les espèces de parasites et déterminer la prévalence de chaque Digène par rapport aux cinq types d'habitats à mollusques. Sept espèces de Digènes ont été trouvées chez 321 mollusques parasités (sur un total de 17647 L. glabra). Les limnées avec F. hepatica ou C. daubneyi ont été récoltées, respectivement, dans $14.5 \%$ et $12.6 \%$ des habitats. Les pourcentages sont plus faibles pour les limnées avec Opisthoglyphe ranae (5.8\%), Haplometra cylindracea $(5.3 \%)$ et sont inférieurs à $5 \%$ pour les mollusques infestés par Echinostoma revolutum, Notocotylus sp. ou Plagiorchis sp. La prévalence notée pour chaque espèce de parasite varie avec le type d'habitat. Le nombre d'espèces chez L. glabra est plus faible que celui trouvé chez les Galba truncatula de la même région (7 au lieu de 10). La distribution et la prévalence de chaque espèce de Digène sont donc dépendantes du type et de la localisation de chaque habitat à limnées.

Freshwater pulmonate gastropods play a significant role in the life cycles of many trematodes, as they ensure development of their larval forms. Examining these gastropods provides information on local parasitological fauna in a given region and on the sources of infection for definitive hosts [12, 31]. Among these gastropods, the family Lymnaeidae can sustain larval development of more than 70 trematode species [5, 24]. Contrary to other lymnaeids for which research on natural infection with trematode larvae has been conducted in Europe for over a hundred years [31], little information on

\footnotetext{
*Corresponding author: gilles.dreyfuss@unilim.fr
}

parasitological fauna developing in the snail Lymnaea glabra O.F. Müller, 1774 [25] is available in the literature. This lymnaeid is known to be a natural intermediate host of two flukes: Calicophoron daubneyi Dinnik, 1962 [9] and Fasciola hepatica Linnaeus, 1758 [23] in central France [1-4]. But it can also sustain larval development of several other digeneans. Rondelaud [27] reported the presence of five digenean species in 13,039 L. glabra collected from several watercress beds located on the cristallophyllian and metamorphic soils of the Limousin region (central France). Overall prevalence was $4.3 \%$ for $F$. hepatica, $2.3 \%$ for $C$. daubneyi, $0.1 \%$ for Haplometra cylindracea Zeder, 1800 [32] and $0.09 \%$ for a total 
Table 1. Frequency of sites colonized by Lymnaea glabra and containing infected snails in relation to the type of habitat and digenean species. $n$, total number of habitats colonized by the lymnaeid.

\begin{tabular}{|c|c|c|c|c|c|c|}
\hline \multirow[t]{2}{*}{ Parasite species } & \multicolumn{6}{|c|}{ Number of habitats containing infected snails (frequency in \%) } \\
\hline & $\begin{array}{l}\text { Drainage furrows } \\
(n: 37)\end{array}$ & $\begin{array}{l}\text { Road ditches } \\
\quad(n: 86)\end{array}$ & $\begin{array}{l}\text { Pools } \\
(n: 28)\end{array}$ & $\begin{array}{l}\text { Pond banks } \\
\quad(n: 31)\end{array}$ & $\begin{array}{l}\text { Brooks } \\
(n: 24)\end{array}$ & $\begin{array}{l}\text { All sites } \\
(n: 206)\end{array}$ \\
\hline Calicophoron daubneyi & $14(37.8)$ & $7(8.1)$ & $3(10.7)$ & 0 & 0 & $24(11.6)$ \\
\hline Echinostoma revolutum & 0 & 0 & 0 & $2(6.4)$ & 0 & $2(0.9)$ \\
\hline Fasciola hepatica & $17(45.9)$ & $11(12.7)$ & $1(3.5)$ & $1(3.2)$ & 0 & $30(14.5)$ \\
\hline Haplometra cylindracea & $2(5.4)$ & 0 & $7(25.0)$ & 0 & $3(12.5)$ & $11(5.3)$ \\
\hline Notocotylus sp. & $1(2.7)$ & $2(0.2)$ & $3(10.7)$ & $2(6.4)$ & $1(4.1)$ & $9(4.3)$ \\
\hline Opisthoglyphe ranae & 0 & 0 & $5(17.8)$ & $7(22.5)$ & 0 & $12(5.8)$ \\
\hline Plagiorchis sp. & 0 & 0 & 0 & $3(9.6)$ & 0 & $3(1.4)$ \\
\hline \multicolumn{7}{|l|}{ Immature infections } \\
\hline with rediae & $1(2.7)$ & 0 & 0 & $2(6.4)$ & $2(8.2)$ & $5(2.4)$ \\
\hline with sporocysts & $3(10.0)$ & $1(0.1)$ & 0 & $3(9.5)$ & $1(4.1)$ & $8(4.0)$ \\
\hline Xiphidiocercariae (unidentified species) & 0 & 0 & $7(25.0)$ & $2(6.4)$ & $1(4.1)$ & $10(4.8)$ \\
\hline Number of parasite species & 4 & 3 & 5 & 5 & 2 & 7 \\
\hline
\end{tabular}

of two unidentified species. In contrast, in the swampy meadows of 18 farms located on the same types of soils, Abrous et al. [3, 4] reported the presence only of $F$. hepatica and/or C. daubneyi in L. glabra. In view of results reported by Rondelaud [27] and Abrous et al. [3, 4], it can be asked whether these findings would be the same in another French region: Did digenean prevalence and species composition change when the L. glabra samples were collected from a close sedimentary area with numerous meadows and ponds? Did prevalences, species composition and richness differ with the different types of snail habitats? To answer these two questions, adult snails were collected in 2014 and 2015 from five types of L. glabra habitats located in the Brenne Regional Natural Park, department of Indre (central France). After collection, snails were dissected to identify parasite species and determine prevalences of natural infections.

Snail investigations were carried out on six close municipalities: Chitray, Ciron, Migné, Nuret-le-Ferron, Rosnay and Ruffec. Five types of L. glabra habitats were identified in 2010-2011: (i) rainwater-draining furrows in meadows (37 habitats), (ii) temporary waterlogged road ditches (86), (iii) small permanent pools $\left(<50 \mathrm{~m}^{2}\right)$ in meadows (28), (iv) banks of larger ponds near water inflows (31) and (v) brooks receiving water coming from upstream ponds (24) (Table 1). The soil of these habitats was composed of silt and sand, and was generally supported by sandstones and/or clay. In these 206 habitats, the total number of overwintering snails per habitat ranged from 84 to 202 adults at the beginning of field investigations (April, May or June 2014 according to the type of snail habitat). The temperate climate was frequently swept by humid winds which came from the West or the South-west [8]. The mean annual rainfall was about $800 \mathrm{~mm}$ and the mean annual temperature was $10.5^{\circ}-11{ }^{\circ} \mathrm{C}$ with rather mild winters [10].

Samples of 50 overwintering L. glabra (shell height, $\geq 8 \mathrm{~mm}$ ) were randomly collected from each habitat in March (sites i-iii), April (sites iv) or May 2014 (sites v). The choice of March, April or May for snail collection was based on the fact that most infected snails, belonging to the overwintering generation, contained free cercariae within their body during this period. In 2015, samples performed in a total of 76 habitats were less than 50 snails because of the partial drying up of these sites during the sampling period and the burying of most overwintering adults into the soil. Owing to this difficulty in 2015, the total number of snails sampled during the two-year study was 17,647 (Table 2). In watered sites, snails were sampled using a $20-\mathrm{cm}$ diameter sieve (mesh size, $0.2 \mathrm{~cm}$ ). After collection, the snails were dissected under a stereomicroscope to detect the presence of trematode larval forms. Those of $C$. daubneyi, F. hepatica and $H$. cylindracea were directly identified because of our experience acquired with natural infections of L. glabra with these digenean species [25]. When larval forms of another trematode were detected, neutral red and/or Nile blue were used to study their morphology. Plagiorchiid cercariae were also heat killed and several dimensions were measured according to the reports by Combes [6] and Grabda-Kazubska [19]. Parasite identification was performed using taxonomic keys by several authors [13-15, 18, 26]. After identification, the prevalence of each parasite infection was determined.

The first parameter was the number of parasite species in each type of snail habitat. The frequency of sites containing snails infected by a digenean was the second parameter and was determined for each type of habitat using the ratio: number of sites with infected snails/total number of snail habitats. Prevalence of each digenean infection and the overall prevalence of parasite species for each type of snail habitat were calculated using the ratio: number of infected snails/total number of sampled L. glabra. In the case of snail co-infections, prevalence was specified for each parasite species. A $\chi^{2}$ test was used to determine levels of statistical significance. Prevalences noted in the same type of habitats were first compared. In a second analysis, the differences between $C$. daubneyi values and those noted for F. hepatica in furrows, road ditches and pools were assessed because snail samples were collected over the same period of time (March). All the analyses were done using StatView 5.0 software (SAS Institute Inc., Cary, 
Table 2. Number of Lymnaea glabra infected by each digenean species and prevalence of natural infection in five types of habitats located in the southern part of the Brenne Regional Natural Park, department of Indre, central France. $n$, total number of adult snails collected during the 2 years of study.

\begin{tabular}{|c|c|c|c|c|c|c|}
\hline \multirow[t]{2}{*}{ Parasite species } & \multicolumn{6}{|c|}{ Number of infected snails (prevalence in \%) } \\
\hline & $\begin{array}{c}\text { Drainage furrows } \\
(n: 3655)\end{array}$ & $\begin{array}{l}\text { Road ditches } \\
(n: 8491)\end{array}$ & $\begin{array}{c}\text { Pools } \\
(n: 2800) \\
\end{array}$ & $\begin{array}{l}\text { Pond banks } \\
(n: 3045)\end{array}$ & $\begin{array}{c}\text { Brooks } \\
(n: 2256) \\
\end{array}$ & $\begin{array}{c}\text { All sites } \\
(n: 17,647) \\
\end{array}$ \\
\hline Calicophoron daubneyi & $51(1.3)$ & $24(0.2)$ & $7(0.2)$ & 0 & 0 & $82(0.4)$ \\
\hline Echinostoma revolutum & 0 & 0 & 0 & $2(0.06)$ & 0 & $2(0.01)$ \\
\hline Fasciola hepatica & $71(1.9)$ & $43(0.5)$ & $2(0.07)$ & $1(0.03)$ & 0 & $117(0.6)$ \\
\hline Haplometra cylindracea & $7(0.1)$ & 0 & $19(0.6)$ & 0 & $5(0.2)$ & $31(0.1)$ \\
\hline Notocotylus sp. & $1(0.02)$ & $2(0.02)$ & $3(0.1)$ & $2(0.06)$ & $1(0.04)$ & $9(0.05)$ \\
\hline Opisthoglyphe ranae & 0 & 0 & $11(0.3)$ & $32(1.0)$ & 0 & $43(0.2)$ \\
\hline Plagiorchis sp. & 0 & 0 & 0 & $3(0.09)$ & 0 & $3(0.01)$ \\
\hline \multicolumn{7}{|l|}{ Immature infections } \\
\hline with rediae & $2(0.04)$ & 0 & 0 & $2(0.06)$ & $2(0.08)$ & $6(0.03)$ \\
\hline with sporocysts & $9(0.2)$ & $2(0.02)$ & $7(0.2)$ & $5(1.6)$ & $2(0.08)$ & $25(0.1)$ \\
\hline Xiphidiocercariae (unidentified species) & 0 & 0 & 0 & $2(0.06)$ & $1(0.04)$ & $3(0.01)$ \\
\hline Total number of infected snails (prevalence in \%) & $141(3.8)$ & $71(0.08)$ & $49(1.7)$ & $49(1.6)$ & $11(0.4)$ & $321(1.8)$ \\
\hline
\end{tabular}

NC, USA). The nomenclature adopted by Correa et al. [7] and that by Jones [21] were used in the present study to identify lymnaeid and paramphistome species, respectively.

Of the 17,647 adult snails collected from the 206 habitats over the 2 years, three plagiorchiid, one echinostomatid, one fasciolid, one notocotylid and one paramphistomid species were found (Table 1). Immature infections without free cercariae were also noted. Those belonging to $C$. daubneyi, $F$. hepatica and $H$. cylindracea were easily recognized because of our experience and were classified with the corresponding snails harbouring mature infections. In contrast, those of the other digenean species were considered separately, taking into account the presence of rediae or secondary sporocysts. Xiphidiocercariae were also noted in the foot of several snails but their characteristics did not allow precise identification of the plagiorchiid species. Eleven double infections with $C$. daubneyi and $F$. hepatica were noted (data not shown).

Table 1 gives the distribution of habitats from which infected lymnaeids were collected. Snails harbouring larval forms of $F$. hepatica and/or $C$. daubneyi were found, respectively, in $14.5 \%$ and $11.6 \%$ of sites investigated. The percentages were lower for snails with Opisthoglyphe ranae Frölich, 1791 [16] (5.8\%) and H. cylindracea (5.3\%), and were less than $5 \%$ for individuals infected by a digenean of the other three species. Most snails infected with $F$. hepatica were collected from rainwater-draining furrows (45.9\%), road ditches (12.7\%) and pools (3.5\%). Similar observations were noted for snails with $C$. daubneyi $(37.8 \%$ of furrows, $8.1 \%$ of road ditches and $10.7 \%$ of pools). These pools were also the main habitats for snails infected with $H$. cylindracea (25.0\%) and $O$. ranae $(17.8 \%)$. The frequency of habitats with snails infected with other parasite species, particularly those with Notocotylus sp., was clearly lower. The highest number of parasite species was noted in pools located in meadows and on pond banks (five species in each case). During the 2 years of study, the presence of $F$. hepatica was regularly noted in snails living in 7 furrows (out of 17 habitats with infected $L$ glabra) and 5 road ditches (out of 11). This was also observed for $C$. daubneyi (7 furrows/14, 3 road ditches/7), $H$. cylindracea (4 pools/7) and $O$. ranae ( 2 pools $/ 5,4$ ponds/ 7 ). In the other types of habitats, the presence of snail infections was more sporadic (data not shown).

Table 2 gives values for each type of snail habitat and each digenean infection. Of the 17,647 L. glabra collected from the five types of habitats, a total of 321 infected snails were noted. The highest overall prevalence of all digenean infections was noted in furrows $(3.8 \%)$, followed by pools $(1.7 \%)$ and ponds $(1.6 \%)$ by decreasing order. In the other two types of habitats, prevalence was $<1 \%$. The percentage noted for each digenean infection varied with the type of habitat. In snails collected from furrows, prevalence of $F$. hepatica $(1.9 \%)$ was slightly higher than that of $C$. daubneyi (1.3\%) but this difference was not significant. Percentages greater than $0.5 \%$ were noted in pools for $H$. cylindracea and in ponds for $O$. ranae. In contrast, the prevalence for the other parasite species was less than $0.5 \%$, whatever the type of habitat. If the values recorded for $F$. hepatica in the different types of habitats were compared, the prevalence of this digenean infection was significantly greater $\left(\chi^{2}=105.16, p<0.001\right)$ in snails living in furrows than in road ditches and pools. In the same way, the value noted for $C$. daubneyi infection was significantly higher $\left(\chi^{2}=93.28\right.$, $p<0.001)$ in snails living in furrows than in road ditches and pools.

Owing to the limited geographic range of L. glabra in Western Europe, from Scandinavia up to Spain [20] and little information available on parasitological fauna in this snail, the results noted in the present study were compared with reports by Rondelaud [27] on L. glabra from the Limousin region and Rondelaud et al. [28] on Galba truncatula O.F. Müller, 1774 [25] from the Brenne Regional Natural Park. Compared to L. glabra samples collected by Rondelaud [27], the number of parasite species was greater in the present study (7 species instead of 5) but was lower than that (10 species) noted in G. truncatula originating from the same six French municipalities [28]. The presence of numerous pools and ponds in the Brenne Regional Natural Park might explain this 
increase in the number of parasite species in our L. glabra. In contrast, the difference noted between $G$. truncatula and L. glabra from the same six municipalities is more difficult to interpret. In our opinion, this discrepancy might be mainly due to the situation of snail habitats along the same hydrographical network: those colonized by G. truncatula were often located at the peripheral extremity of rainwater-draining and open drainage furrows, for example, while those inhabited by L. glabra in the same furrows were found more downstream [11]. However, another explanation based on the abundance of both lymnaeid species in the Brenne Regional Natural Park (the size of L. glabra populations was clearly greater than that of G. truncatula populations [30]) cannot be completely excluded.

Most L. glabra infected with F. hepatica and/or C. daub$n e y i$ were found in snail samples collected from furrows and this result was consistent with the report by Rondelaud et al. [28] on G. truncatula. In contrast, the L. glabra infected by either digenean were more numerous in road ditches and scarcer in pools. In contrast, the distribution of infected $G$. truncatula in both these types of habitats was the opposite [28]. Three points may explain this difference, (i) the presence of more L. glabra populations in road ditches which bordered cattleor sheep-grazed meadows than in pools [30], (ii) the flow of runoff coming from these meadows into these ditches, particularly in winter and spring, and (iii) the location of L. glabra among amphibious and/or floating vegetation in the center of pools, while the G. truncatula population was often found on the margins of these sites (unpublished data). The presence of the echinostomatid and plagiorchiid species in pools and ponds was consistent with the report of Rondelaud et al. [28] on the $G$. truncatula from the same French municipalities. Similarly, the findings of Notocotylus sp. in snails collected from the five types of habitats confirm presence of this parasite in local G. truncatula [28].

In L. glabra, the prevalence of F. hepatica infection varied with the type of habitat and was significantly higher in furrowcollected snails than in those coming from road ditches and pools. A similar finding was also noted for prevalence of C. daubneyi. These variations in both prevalences may be explained by two points: (i) both digeneans often used the same definitive and intermediate hosts for their life cycle [22], and (ii) the co-infection of pre-adult L. glabra (4 mm in shell height) with both types of miracidia often resulted in complete larval development of F. hepatica, C. daubneyi or both [1-4]. Prevalence of $H$. cylindracea $(0.6 \%)$ in poolcollected L. glabra was clearly higher than that $(0.1 \%)$ reported by Rondelaud [27] for the same lymnaeid in wild watercress beds. This difference might be due to the fact that infected frogs (the definitive host of this digenean) would infect numerous snails during their stay in pools. The finding of numerous $H$. cylindracea-infected G. truncatula in the populations studied by Vignoles et al. [29] between 2001 and 2009 on acid soils supports this last hypothesis. In the present study, larval forms of four other digenean species were also found in the body of L. glabra (Table 2). The most frequent was O. ranae with $0.3 \%$ and $1 \%$ prevalences in pools and ponds, respectively. As no larval forms of these four digeneans were reported by Rondelaud [27] in the L. glabra from the Limousin region, this paper was the first report of this lymnaeid as intermediate host for Echinostoma revolutum Frölich, 1802 [17], Notocotylus sp., $O$. ranae and Plagiorchis sp.

In conclusion, the L. glabra living in the Brenne Regional Natural Park acted as intermediate hosts in the life cycles of seven digeneans. The highest prevalences were noted for $C$. daubneyi and F. hepatica. The distribution and prevalence of each parasite species were dependent on the type and, consequently, the location of each snail habitat.

\section{References}

1. Abrous M, Rondelaud D, Dreyfuss G. 1996. Paramphistomum daubneyi and Fasciola hepatica: the effect of dual infection on prevalence and cercarial shedding in preadult Lymnaea glabra. Journal of Parasitology, 82, 1026-1029.

2. Abrous M, Rondelaud D, Dreyfuss G, Cabaret J. 1998. Unusual transmission of the liver fluke, Fasciola hepatica, by Lymnaea glabra or Planorbis leucostoma in France. Journal of Parasitology, 84, 1257-1259.

3. Abrous M, Rondelaud D, Dreyfuss G, Cabaret J. 1999. Infection of Lymnaea truncatula and Lymnaea glabra by Fasciola hepatica and Paramphistomum daubneyi in farms of central France. Veterinary Research, 30, 113-118.

4. Abrous M, Rondelaud D, Dreyfuss G. 2000. A field study of natural infections in three freshwater snails with Fasciola hepatica and/or Paramphistomum daubneyi in central France. Journal of Helminthology, 74, 189-194.

5. Brown DS. 1978. Pulmonate molluscs as intermediate hosts for digenetic trematodes, in Pulmonates, vol 2A, Systematics, evolution and ecology, Fretter V, Peake J, Editors. Academic Press: London. p. 287-333.

6. Combes C. 1968. Biologie, écologie des cycles et biogéographie de Digènes et Monogènes d'Amphibiens dans les Pyrénées. Mémoires du Muséum National d'Histoire Naturelle, $51,1-191$.

7. Correa AC, Escobar JS, Noya O, Velásquez LE, GonzálezRamírez C, Hurtrez-Boussès S, Pointier JP. 2011. Morphological and molecular characterization of Neotropic Lymnaeidae (Gastropoda: Lymnaeoidea), vectors of fasciolosis. Infection, Genetics and Evolution, 11, 1978-1988.

8. Dauphin P. 2012. Document d'objectifs des sites Natura 2000 FR2410003 "Brenne » et FR2400534 " Grande Brenne ». http://www.donnees.centre.développement-durable.gouv.fr/ ...Brenne/DOCOB_Brenne.pdf (Consulted on January 19, 2015).

9. Dinnik JA. 1962. Paramphistomum daubneyi sp. nov. from cattle and its snail host in the Kenya Highland. Parasitology, 52, 143-151.

10. Dreyfuss G, Vignoles P, Rondelaud D. 2010. Omphiscola glabra (Gastropoda, Lymnaeidae): changes occurring in natural infections with Fasciola hepatica and Paramphistomum daub$n e y i$ when this snail species is introduced into new areas. Annales de Limnologie-International Journal of Limnology, 46, 191-197.

11. Dreyfuss G, Vignoles P, Rondelaud D, Cabaret J. 2015. The mud snail (Galba truncatula). Ecology, parasitism and control. Lambert Academic Publishing: Saarbrücken. p. 238.

12. Faltýnková A. 2005. Larval trematodes (Digenea) in molluscs from small water bodies near České Budéjovice, Czech Republic. Acta Parasitologica, 50, 49-55. 
13. Faltýnková A, Nasincová V, Kablásková L. 2007. Larval trematodes (Digenea) of the great pond snail, Lymnaea stagnalis (L.), (Gastropoda, Pulmonata) in Central Europe: a survey of species and key of their identification. Parasite, 14, $39-51$.

14. Faltýnková A, Nasincová V, Kablásková L. 2008. Larval trematodes (Digenea) of planorbid snails (Gastropoda: Pulmonata) in Central Europe: a survey of species and key to their identification. Systematic Parasitology, 69, 155-178.

15. Frandsen F, Christensen NO. 1984. An introductory guide to the identification of cercariae from African freshwater snails with special reference to cercariae of trematode species of medical and veterinary importance. Acta Tropica, 41, 181-202.

16. Frölich JA. 1791. Beiträge zur Naturgeschichte der Eingeweidewürmer. Der Naturforscher, 25, 52-113.

17. Frölich JA. 1802. Beiträge zur Naturgeschichte der Eingeweidewürmer. Der Naturforscher, 29, 5-96.

18. Fuchs C, Mannesmann R. 2003. The indigenous fauna of Trematodes. www.uni-bielefeld.de/biologie/Didaktik/Zoologie/ html_eng/trematoden_eng.html (Consulted between March 23 and June 17, 2014).

19. Grabda-Kazubska B. 1970. Studies on the life cycle of Haplometra cylindracea (Zeder, 1800) (Trematoda: Plagiorchiidae). Acta Parasitologica Polonica, 18, 497-512.

20. Hubendick B. 1951. Recent Lymnaeidae. Their variation, morphology, taxonomy, nomenclature, and distribution. Küngliga Svenska Vetenskapsakademiens Handlingar, 3, $1-223$.

21. Jones A. 1901. Family Paramphistomidae Fischoeder, 1901. In Jones A, Bray RA, Gibson DI, Editors. Keys to the Trematoda, vol. 2, CAB International and the Natural History Museum: London. p. 229-246.

22. Kilani M, Chermette R, Guillot J, Polack B, Duncan JL, Cabaret J. 2010. Gastrointestinal helminthoses: amphistomosis. In Lefèvre PC, Blancou J, Chermette R, Uilenberg G, Editors. Infectious and parasitic diseases of livestock, Éditions Lavoisier, Paris, pp. 1589-1601.
23. Linnaeus C. 1758. Systema Naturae per regna tria naturae, secundum classes, ordines, genera, species, cum characteribus, differentiis, synonymis, locis, 10th ed. Vermes, Testacea, pp. 700-781. Holmiae (Salvius).

24. Mas-Coma S, Bargues MD, Valero MA. 2005. Fascioliasis and other plant-borne trematode zoonoses. International Journal for Parasitology, 35, 1255-1278.

25. Müller OF. 1773-1774. Vermium terrestrium et fluviatilium, seu animalium infusoriorum, helminthicorum, et testaecorum, non marinorum, succincta historia. Vol. 1, unpaginated preface, bibliography and table of contents, $32 \mathrm{pp}$., and 1-136 [1773]; pars altera, 1-72, and unpaginated index, 10 pp. [1774]; vol. 2, pp. I-XXVI [= 1-36], 1-214 [1774]. Havniæ [Copenhagen] \& Lipsiæ [Leipzig] (Heineck \& Faber).

26. Nasir P, Erasmus DA. 1964. A key to the cercariae from British freshwater molluscs. Journal of Helminthology, 38, 245-268.

27. Rondelaud D. 2004. Cressonnières naturelles du Limousin et risques de distomatose humaine à Fasciola hepatica. Annales Scientifiques du Limousin, 15, 1-14. Published online in Annales Scientifiques du Naturaliste (2012).

28. Rondelaud D, Vignoles P, Dreyfuss G. 2015. Larval trematode infections in Galba truncatula (Gastropoda, Lymnaeidae) from the Brenne Regional Natural Park, central France. Journal of Helminthology, online.

29. Vignoles P, Dreyfuss G, Rondelaud D. 2011. Haplometra cylindracea: variation in the dates of cercarial shedding for overwintering Galba truncatula. Parasite, 18, 181-184.

30. Vignoles P, Rondelaud D, Dreyfuss G. 2015. La Limnée étroite (Omphiscola glabra O.F. Müller, 1774) : l'abondance des mollusques adultes dans le centre de la France par rapport à la nature géologique du sol et la présence d'autres Pulmonés aquatiques dans les mêmes habitats. MalaCo, 11, 1-5.

31. Żbikowska E, Nowak A. 2009. One hundred years of research on the natural infection of freshwater snails by trematode larvae in Europe. Parasitology Research, 105, 301-311.

32. Zeder JGH. 1800. Erster Nachtrag zur Naturgeschichte der Eingeweidewürmer, mit Zusätzen und Anmerkungen herausgegeben. Leipzig, $\mathrm{xx}+320 \mathrm{pp}$.

Cite this article as: Rondelaud D, Vignoles P \& Dreyfuss G: Larval trematode infections in Lymnaea glabra populations living in the Brenne Regional Natural Park, central France. Parasite, 2015, 22, 38.

Reviews, articles and short notes may be submitted. Fields include, but are not limited to: general, medical and veterinary parasitology; morphology, including ultrastructure; parasite systematics, including entomology, acarology, helminthology and protistology, and molecular analyses; molecular biology and biochemistry; immunology of parasitic diseases; host-parasite relationships; ecology and life history of parasites; epidemiology; therapeutics; new diagnostic tools.

All papers in Parasite are published in English. Manuscripts should have a broad interest and must not have been published or submitted elsewhere. No limit is imposed on the length of manuscripts.

Parasite (open-access) continues Parasite (print and online editions, 1994-2012) and Annales de Parasitologie Humaine et Comparée (1923-1993) and is the official journal of the Société Française de Parasitologie. 